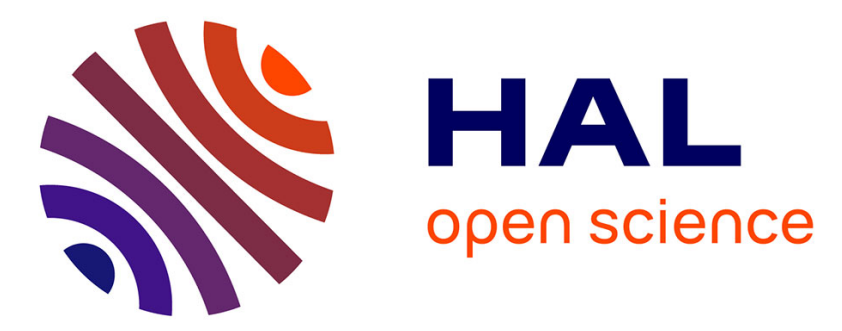

\title{
Mathematical Modeling of Broccoli Cultivation and Growth Period and Yield of Flower Heads
}

\author{
Liu Wei-Ming, Wang En-Guo
}

\section{To cite this version:}

Liu Wei-Ming, Wang En-Guo. Mathematical Modeling of Broccoli Cultivation and Growth Period and Yield of Flower Heads. 8th International Conference on Computer and Computing Technologies in Agriculture (CCTA), Sep 2014, Beijing, China. pp.94-98, 10.1007/978-3-319-19620-6_12 . hal01420219

\section{HAL Id: hal-01420219 \\ https://hal.inria.fr/hal-01420219}

Submitted on 20 Dec 2016

HAL is a multi-disciplinary open access archive for the deposit and dissemination of scientific research documents, whether they are published or not. The documents may come from teaching and research institutions in France or abroad, or from public or private research centers.
L'archive ouverte pluridisciplinaire HAL, est destinée au dépôt et à la diffusion de documents scientifiques de niveau recherche, publiés ou non, émanant des établissements d'enseignement et de recherche français ou étrangers, des laboratoires publics ou privés. 


\title{
Mathematical modeling of broccoli cultivation and growth period and yield of flower heads
}

\author{
Liu Wei-ming ${ }^{1, a}$, Wang En-guo ${ }^{2, b}$ \\ ${ }^{1}$ Taizhou Vocational College of Science \& Technology, Taizhou, Zhejiang 318020 \\ ${ }^{2}$ Plant Protection Station of Linhai, Linhai 317000, China \\ a15157622288@139.com
}

\begin{abstract}
This study was carried out to evaluate the effects of transplant age, planting density and the level of nitrogen fertilizer on growth period and yield of broccoli. Two mathematical models were constructed for these parameters, they are $y_{1}=75.1322+1.6361 x_{1}-0.0001 x_{2}+0.0014 x_{3}$ $\left(R=0.8888^{* *}\right)$, and $y_{2}=14999.1852+404.0006 x_{1}-0.1986 x_{2}+3.6196 x_{3}$ ( $R=0.6058^{* *}$ ), where $y_{1}$ and $y_{2}$ are growth period and yield, and $x_{1}, x_{2}, x_{3}$ are transplant age, planting density and dose of nitrogen fertilizer, respectively. These models can be used for the optimization of cultivation techniques to achieve the goal of developing an high yield and high profit competitive broccoli production system.
\end{abstract}

Key words: broccoli, transplant age, planting density, nitrogen fertilizer level, growth period, yield, mathematical model

\section{Introduction}

Transplant age, planting density and the amount of nitrogen fertilizer are important cultivation factors influencing quality of broccoli and profit of the crop. Previously, these three factors were evaluated for their effects on growth period and yield of broccoli [1-9], but no mathematical model systems were established. This study aimed at developing a simulation modeling system for providing scientific information for decision making in secure high yield and high profit production of broccoli.

\section{Material and methods}

\subsection{Experimental design}


Broccoli cultivar, Luxiong90, was chosen in this study. There were six treatments of transplant age of 25, 30, 35, 40, 45, 50 days. Planting density had seven treatments of 24000 plants $/ \mathrm{hm} 2,27750$ plants/hm2, 30000 plants $/ \mathrm{hm} 2,33000$ plants $/ \mathrm{hm} 2,36750$ plants $/ \mathrm{hm} 2,42000$ plants $/ \mathrm{hm} 2$ and 48000 plants $/ \mathrm{hm} 2$. In these treatments, the inter-row and between plant spacing were $0.6 \times 0.7 \mathrm{~m}, 0.6 \times 0.6 \mathrm{~m}, 0.6 \times 0.55 \mathrm{~m}$, $0.6 \times 0.5 \mathrm{~m}, 0.6 \times 0.45 \mathrm{~m}, 0.6 \times 0.4 \mathrm{~m}$ and $0.6 \times 0.35 \mathrm{~m}$. For nitrogen fertilizer treatments, four level treatments using pure $\mathrm{N}$ each at a rate of $150,375,600$ and $825 \mathrm{~kg} / \mathrm{hm} 2$ were applied following the schedule in Table 1 . In each treatment, three replicates were planted using randomized block design. The plot size was $12 \mathrm{~m} 2$ for transplant age treatments, $18 \mathrm{~m} 2$ for planting density treatments, and $15 \mathrm{~m} 2$ for fertilizer treatments.

Table 1 Experimental design of the nitrogen fertilizer treatment experiment

\begin{tabular}{cccccc}
\hline & \multicolumn{5}{c}{ Schedule of application of nitrogen fertilizer (kg/hm2) } \\
\cline { 2 - 6 } Total pure N & $\begin{array}{c}\text { First top } \\
\text { dressing } \\
\text { (Oct.22) }\end{array}$ & $\begin{array}{c}\text { Second } \\
\text { top-dressing } \\
\text { (Nov. 08) }\end{array}$ & $\begin{array}{c}\text { Flower bud } \\
\text { differentiation } \\
\text { fertilizer } \\
\text { (Nov. 27) }\end{array}$ & $\begin{array}{c}\text { Budding } \\
\text { fertilizer } \\
\text { (Dec. 13). }\end{array}$ & $\begin{array}{c}\text { Heading } \\
\text { fertilizer } \\
\text { (Dec. 21) }\end{array}$ \\
\hline 150 & 15 & 30 & 30 & 45 & 30 \\
375 & 37.5 & 75 & 75 & 112.5 & 75 \\
600 & 60 & 120 & 120 & 180 & 120 \\
825 & 82.5 & 165 & 165 & 247.5 & 165 \\
\hline
\end{tabular}

\subsection{Construction of mathematical models and simulation}

Units used in this study were as follows: transplant age (Days), planting density (Plants/hm2), and nitrogen fertilizer doses: $\mathrm{kg} / \mathrm{hm} 2$; growth period (days); yield $(\mathrm{kg} / \mathrm{hm} 2)$.

Data were subjected to polynomial regression analysis using DPS software [10] to build models for transplant age, planting density, nitrogen fertilizer levels, and their relationship with growth period, and yield. These models were used to simulate the cultivation system for broccoli.

\section{Results and analysis}

\subsection{The effects of transplant ages on growth period and yield of broccoli}

The growth periods of broccoli varied greatly among those transplant age treatments, it was from 113 to 162 days. In general when using older transplants, the number of days increased during the period from transplanting to floral bud emergence, the 
duration of vegetative growth post transplanting, floral head growth period, the duration from transplanting to harvest, and total growth period. Statistical analysis identified a significant linear correlation between transplant age $\left(x_{1}\right)$ and growth period $(g)$. The regression model is $g=1.8343 x_{1}+65.381 \quad(r=0.9963 * *)$. However, the density of florets on flower heads, the ratio of marketable flower heads and yield of flower head showed a "low-high-low" trend in responses to increasing transplant age. The regression mathematical model for transplant age $\left(x_{1}\right)$ and flower head yield $(y)$ is: $y=-40.497 x_{1}^{2}+3089 x_{1}-31257\left(r=0.9721^{* *}\right)$.

\subsection{Effects of planting density on growth period and yield of broccoli}

Results indicate that increasing planting density led to decreases in plants height, canopy width, and the number of leaves per plant. Floral buds emerged prematurely, which resulted in shortened growth period. Statistical analysis indicated that planting density $\left(x_{2}\right)$ had a significant linear correlation with the length of period (days) from transplanting to bud emergence $(f)$, and total growth period $(g)$. The regression mathematical models are: $f=73.867-0.0005 x_{2} \quad\left(r=-0.9662^{* *}\right)$ and $g=153.71-0.0006 x_{2} \quad\left(r=-0.9663^{* *}\right)$. Among all the planting density treatments, the highest yield was produced in plots of 36750 plants $/ \mathrm{hm} 2$, it was $32622 \mathrm{~kg} / \mathrm{hm} 2$. The yield was $32127.0,30088.5,29232.0,28153.5,28101.0$, and $25357.5 \mathrm{~kg} / \mathrm{hm} 2$ from treatments of 33000, 42000, 30000, 48000, 27750, and 24000 plants/hm2, respectively. Statistical analysis indicated that planting density $\left(x_{2}\right)$ and flower head yield $(y)$ had an extremely significant binominal correlation. The regression model is: $y=-0.00004 x_{2}^{2}+2.8151 x_{2}-21740,(r=0.9571 * *)$.

\subsection{Effects of nitrogen fertilizer level on growth period and yield of broccoli}

Results in Table 2 show that when nitrogen fertilizer was provided at $600 \mathrm{~kg} / \mathrm{hm} 2$, plants produced the flower heads of the biggest diameter $(13.3 \mathrm{~cm})$, fresh weight per head $(476.85 \mathrm{~g})$ and total yield $(1440.7 \mathrm{~kg} / 667 \mathrm{~m} 2)$. However, these values started to decline at increasing nitrogen level. Florets became thinner at higher nitrogen level. The width of florets in the high nitrogen level treatments was significantly lower than those supplied with lower doses of nitrogen fertilizer. The highest ratio of marketable flower heads was found in the $375 \mathrm{~kg} / \mathrm{hm} 2$ of nitrogen fertilizer treatment, it was $89.6 \%$. Nitrogen fertilizer applied at below of above this dose both resulted in reduced ratio of marketable flower heads. The lowest ratio of $76.2 \%$ was found in the treatment of $150 \mathrm{~kg} / \mathrm{hm} 2$. Statistical analysis revealed a binomial curve changes in flower head yield $(y)$ with nitrogen fertilizer level $\left(x_{3}\right)$. The regression model is: 
$y=-0.03 \quad x_{3}^{3}+32.986 x_{3}+12999\left(r=0.9870^{* *}\right)$.

Table 2 Effects of nitrogen fertilizer levels on marketable quality of flower heads of broccoli

\begin{tabular}{cccccc}
\hline $\begin{array}{c}\text { Nitrogen } \\
\text { fertilizer rate } \\
\left(\mathrm{kg} / \mathrm{hm}^{2}\right)\end{array}$ & $\begin{array}{c}\text { Diameter of } \\
\text { the flower } \\
\text { head }(\mathrm{cm})\end{array}$ & $\begin{array}{c}\text { Weight per } \\
\text { head }(\mathrm{g})\end{array}$ & $\begin{array}{c}\text { Size of } \\
\text { floral buds } \\
\left(\mathrm{cm}^{2}\right)\end{array}$ & $\begin{array}{c}\text { Ratio of } \\
\text { marketable } \\
\text { flower } \\
\text { heads }(\%)\end{array}$ & $\begin{array}{c}\text { Yield } \\
\left(\mathrm{kg} / \mathrm{hm}^{2}\right)\end{array}$ \\
\hline 150 & 12.5 & 421.35 & 76 & 76.2 & 17142 \\
375 & 13.2 & 450.6 & 87 & 89.6 & 21545 \\
600 & 13.3 & 476.85 & 102 & 83.8 & 21611 \\
825 & 12.8 & 469.95 & 116 & 79.4 & 19944 \\
\hline
\end{tabular}

3.4 Construction and the use of polynomial decision-making mathematical models in broccoli production

\subsubsection{Construction of mathematical models}

Data of growth periods and yield of broccoli from treatments of transplant age, planting density, nitrogen fertilizer doses were analyzed using stepwise regression analysis. The polynomial regression models for total growth period $\left(y_{1}\right)$, transplant age $\left(x_{1}\right)$, planting density $\left(x_{2}\right)$, nitrogen fertilizer doses $\left(x_{3}\right)$ are as follows: $y_{1}=75.1322+1.6361 x_{1}-0.0001 x_{2}+0.0014 x_{3}\left(R=0.8888^{* * *}\right) ; \quad$ and the model for yield $\left(y_{2}\right)$ is : $y_{2}=14999.1852+404.0006 x_{1}-0.1986 x_{2}+3.6196 x_{3}$, $\left(R=0.6058^{* *}\right)$.

\subsubsection{The application of the polynomial decision making mathematical model}

Mathematical models can be used to simulate and select the optimum combinations of parameters according to market demand and goals of production. For example, in case of a planting scheme comprised of 130-140 day growth season with targeted yield of $24000-26000 \mathrm{~kg} / \mathrm{hm}^{2}$, the planting density, seedling age and nitrogen fertilizer (pure $\mathrm{N}$ ) combination should be 35-40 day transplants, at a density of $33000-36750$ plants $/ \mathrm{hm}^{2}$, and with the use of $375-600 \mathrm{~kg} / \mathrm{hm}^{2}$ of nitrogen fertilizer. The priority goal of growing broccoli is profit. Because profit is affected by market price, there are differences between yield and profit during some seasons. These modules can be used to arrange production schedule by taking into considerations of predicted market demands and unit price of broccoli. 


\section{Conclusions and discussions}

4.1 Planting older transplants lengthens growth duration, and planting at higher density shortens the period of growth and development of broccoli plants.

This study indicates that the growth period of broccoli plants varied significantly under different transplant ages and planting densities. The growth period changed from 113 to 161 days. In general, when older transplants were used, it lengthened the duration from transplanting to floret emergence, the vegetative growth period in the field, flower head development stage, days from transplanting to harvest, and the duration of growth period. There was an extremely significant correlation between treatments of transplant age and the duration of those growth period.

The growth period was 126-142 days in the planting density treatments. Under high planting density, florets emerged soon after transplanting, and the whole growth period became short. These information are very important when making recommendation for a secure production strategy of broccoli.

\subsection{The yield of flower heads has a binominal curve relationship with transplant} age, planting density and nitrogen fertilizer level

Results indicate that the yield of flower heads followed a non-linear "low-high-low" trend in response to increasing levels of transplant age, planting density and nitrogen fertilizer level treatments. Therefore, in cultivation of broccoli crop, it is very important to pay attention to appropriate combinations of transplant age, planting density and the amount of nitrogen fertilizer.

\subsection{The polynomial mathematical models can provide information to decision} making in designing schemes for the production of broccoli

The polynomial regression models constructed in this study can simulate the effects of transplant age, planting density, nitrogen fertilizer doses on growth period and yield. These models are very useful in designing schemes in response to market demands with specific goals, and guide production management of the broccoli crop.

\section{References}

1. Effects of Different Treatment levels of nitrogen Fertilizer on Yield and Quality of Broccoli. Northern Horticulture.,2006 (1):6-7.

2. Effects of application of nitrogen fertilizer at different growth stage on yield and quality of 
broccoli. Acta Agriculture Shanghai,2008,24（2）:78-80.

3. Effects of nitrogen and Ca nutrients on quality of broccoli. Journal of Zhejiang Agricultural Sciences,2005 (5) :346-348.

4. A study of sowing date and density on fall broccoli. China Vegetables, 1998 (3) :35-35.

5. A study of planting density and fertilizer on broccoli.Inner Mongolia Agricultural Science and Technology, 2005, (6): :41-42,53.

6. Effect of Main Cultural Techniques on Production and Quality Of Broccoli. Chinese Agricultural Science Bulletin,2011, 23(6):545-551.

7. Effect of cultivar, density and nitrogen fertilizer on yield of broccoli. Vegetables,2001 (9) :27-28.

8. Effect of Main Cultural Techniques on Production and Quality Of Broccoli. Chinese Agricultural Science Bulletin,2010,26 (15):274-280.

9. Studies on the Techniques of the Plug Seedlings in Broccoli. Chinese Agricultural Science Bulletin,2010,26 (2):171-175.

10. Applied Statistics and SPS Data Processing System. Beijing: Science Press. 2002 